\title{
Research on consumer spending in Romania
}

\author{
I L Petre ${ }^{1}, \mathrm{M} \mathrm{Nica}^{2}$ and C Caraman ${ }^{3}$ \\ ${ }_{1,2,3} \mathrm{PhD}$ Student, Bucharest University of Economic Studies, Bucharest, Romania \\ E-mail: laurpetre15@gmail.com
}

\begin{abstract}
This article proposes the research of the consumption expenditures in Romania in relation to the income. Thus, with the help of the data provided by the national bases, respectively the National Institute of Statistics on the evolution of the total consumption expenses, of the food expenses and the evolution of the incomes, it was possible to determine the influence that they have on the consumption, respectively the expenses. By making two simple linear regression models it was possible to determine the equation of the function in which both total consumption expenditure and consumption food expenditure could be expressed according to the level of income.
\end{abstract}

Keywords. Consumer spending, food consumption, income, Romania

\section{Introduction}

Food consumption is an essential determinant of the nutritional adequacy and general health of a country's population. A healthy population provides human capital and productive workforce essential for fueling growth and productivity. Currently, about one-eighth of the world's population suffers from hunger, most of the hungry people living in poor countries where poor public health related to food deficiency is one of the main obstacles to economic growth. Although food expenditure in poor countries represents most of the total consumption expenditure, food intake is insufficient and is aggravated by the disappearance of food access between different socio-economic groups.[1]

Increasing the diversity of food consumption in certain geographical areas has important implications for the world and regional trade in agri-food products and for the development of the economy in general. [2]

Food products have always been an important component of Romania's social and economic good. Major changes induced by the process of transition from an order to a more market-oriented economy have given greater importance to food policy. The dramatic increase in food prices and the decrease in real incomes for most of the population had major consequences on the importance assumed by food in household consumption expenditure. [3]

Compared to other European countries, the current level of consumption of different categories of food, such as dairy products, meat products, bakery products, processed fruits and vegetables, fish products, seafood, processed potatoes is quite limited in Romania. However, the purchasing power is increasing in the current period, as well as the increase in consumption registered in Romania, it is also expected to see an increase in the purchase of all types of food. [5] 


\section{Material and method}

This paper aims at a socio-economic analysis of consumer spending in Romania, with an emphasis on food. For this, in the first part of the paper, with the help of the statistical data taken from the national databases (National Institute of Statistics), a quantitative and qualitative analysis of certain indicators will be performed, such as: total consumption expenses, food expenses, total income obtained by to a household and the number of members of a household. In the second part of the paper we will try to determine the reciprocal influences between these indicators, thus, also with the same data, we will analyze from a statistical point of view the relations of interdependence between this variable, with the help of the correlation coefficient and with the help of the simple linear regression model.

\section{Results and discussions}

Considering the objective of this paper, respectively, to study consumer spending in Romania, especially those related to food, an analysis of the statistical data on their evolution will be carried out in the first part of these sections.

Before analyzing the consumption food expenditures, it is proposed to study the total consumption expenditures in Romania in order to be able to create an overview on this aspect.

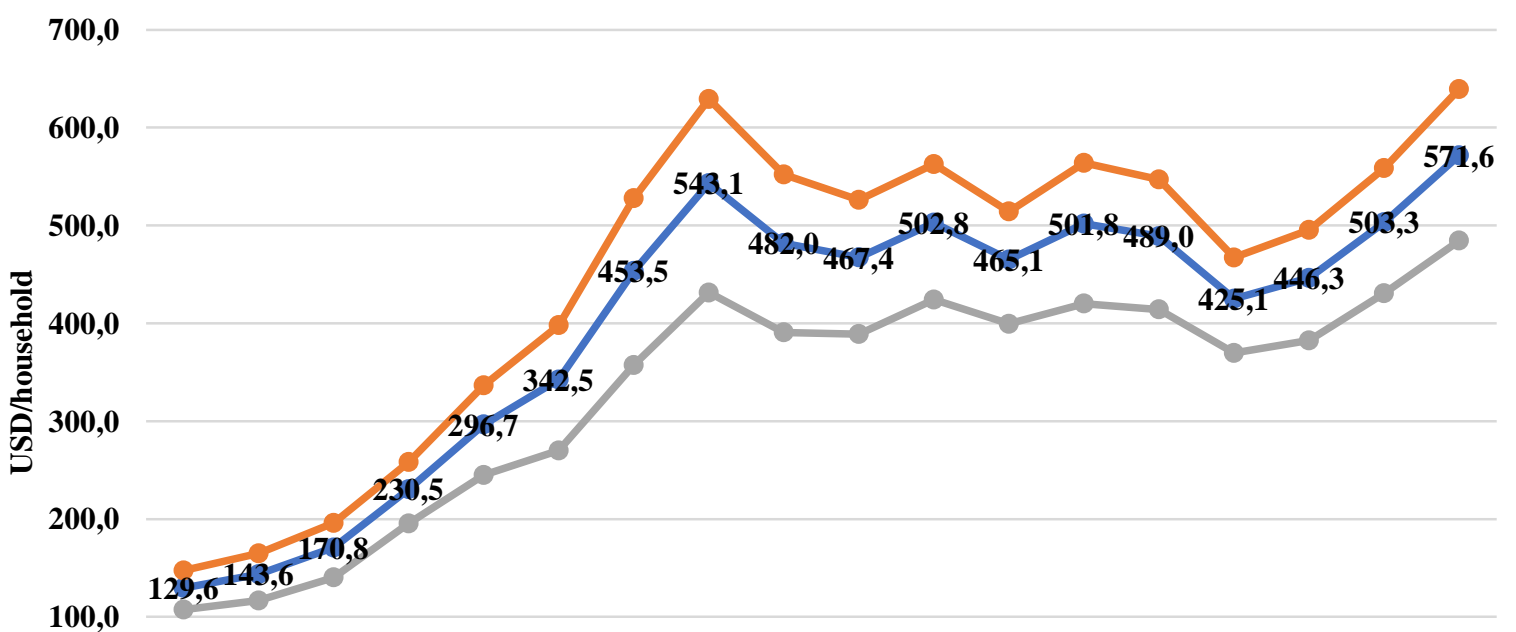

$\mathbf{0 , 0}$

200120022003200420052006200720082009201020112012201320142015201620172018

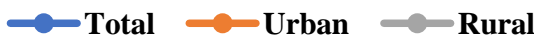

Figure 1. The evolution of the total consumption expenditure in Romania by residence area Source: own processing based on NIS data, http://statistici.insse.ro:8077/tempo-online/

Figure 1 shows the evolution of the total consumption expenditure in Romania at national level and by residence area, between 2001-2018. As you can see, there is an overall growth. If, in 2001, the consumption expenditures on a household were about 130 dollars, they increased until the year of Romania's accession to the EU (2007) constantly every year, reaching 543 dollars per household, in the following period they fluctuated from year to year, and in 2018 the total consumption expenditures in Romania reached about 572 dollars. The average annual growth rate of $9.12 \%$ is recorded throughout the period. On average, there is a total national consumption value of $\$ 398$ per household. As can be seen, also in figure 1, analyzing according to the area of residence, both urban and rural expenditures follow the same trend, but at different levels, urban expenditure is higher than the national average, and from rural being below the national average. On average, in the urban area, more is spent by $12.8 \%$, and in the rural area, it is spent by $16.7 \%$ less than the national average. 


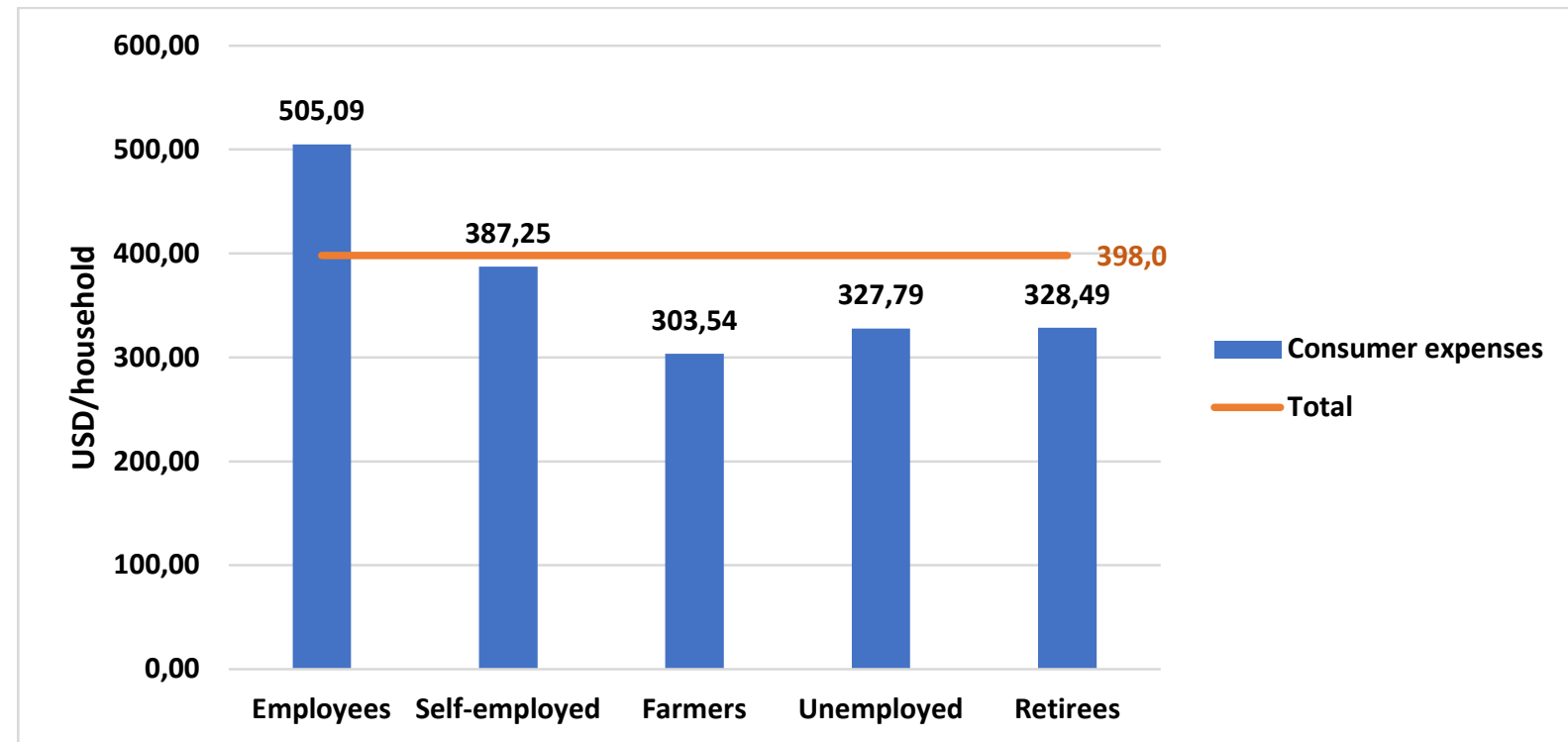

Figure 2. Average total consumption expenditures according to occupational status Source: own processing based on NIS data, http://statistici.insse.ro:8077/tempo-online/

Figure 2 shows the levels of consumption expenditures, compared to the national average, according to the employment status. Thus, as can be seen the only status that exceeds the national average is that of the employees, they spend on average, between 2001 and 2018 about \$ 505, being above the average by $26.9 \%$. The total consumption expenditures of self-employed workers are below the average of 387 dollars (by $2.71 \%$ ), those of agriculture are the lowest being about 304 dollars (below the average with 23.7\%), those of the unemployed being \$ 328 (below average 17.65\%), and those of pensioners being $\$ 328.5$, being lower than the national average by $17.5 \%$.

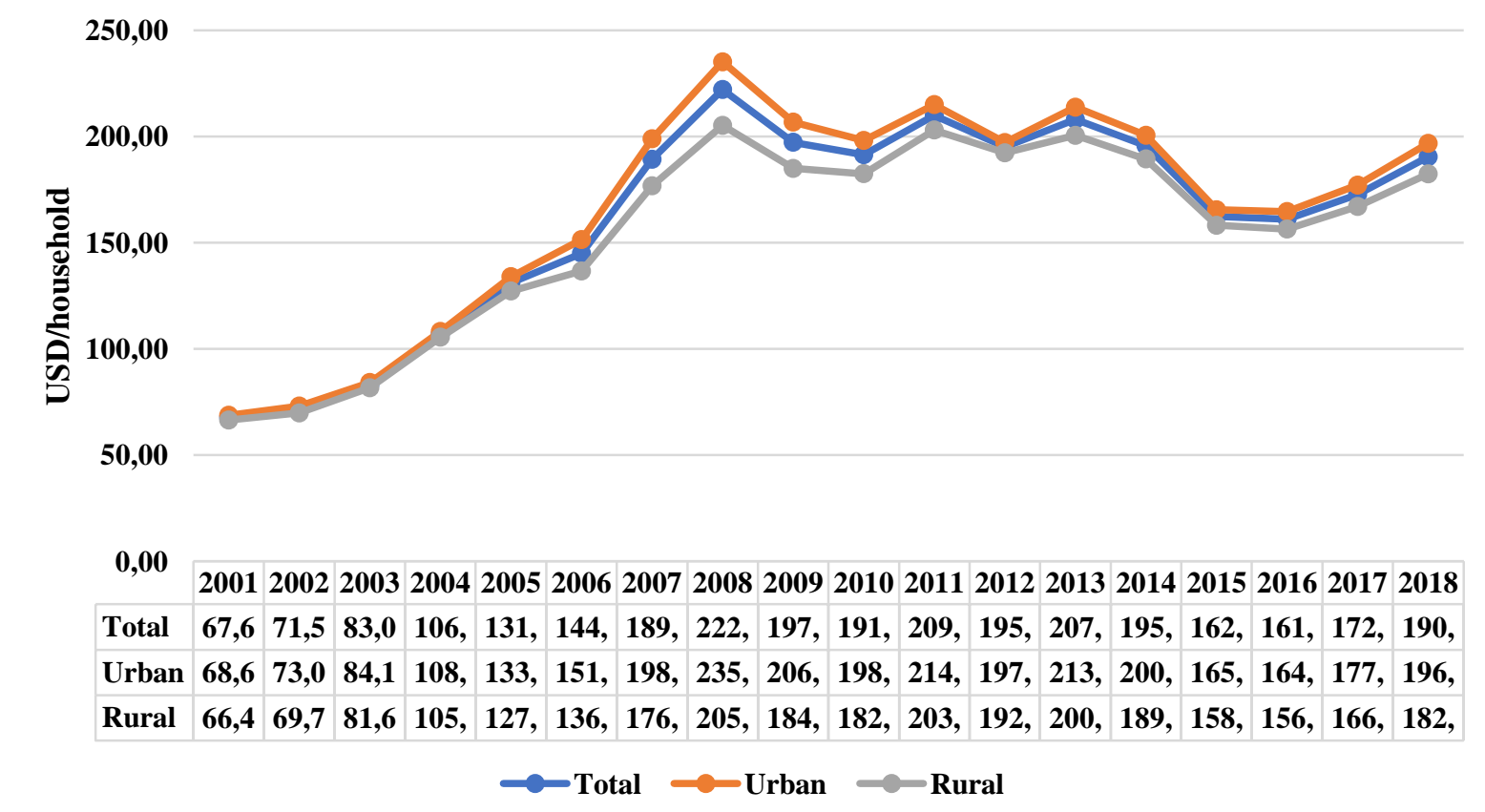

Figure 3. Evolution of consumption food expenses in Romania by residence area Source: own processing based on NIS data, http://statistici.insse.ro:8077/tempo-online/ 
Figure 3 shows the evolution of consumption food expenditures in Romania, at national level and by residence area, thus their tendency is similar to that of total expenditure, thus, if in 2001 there was an expenditure with food of $\$ 68$ per household, in 2008 it reached the maximum of $\$ 222$ per household this period of time being known as an economic ascent in conjunction with Romania's entry into the EU, which opened the market more and more. In 2018, there is a level of food expenses per household of $\$ 190$. Thus, during the period there is an average growth rate of $6.27 \%$ per year, and an average value of food expenses of $\$ 161$ per household. Similarly, food expenditure in the urban area is higher (by 3\%) and those in the rural area are lower by $4 \%$.

Realizing the ratio between food and total expenses, it can be appreciated that, on average, during the analysis period, food expenses represent about $40.5 \%$ of the total. A surprising situation can be seen in the weighting according to the residence areas, in the urban area the share of food expenses is $37 \%$, and in the rural area the weight is $46.7 \%$, surprising considering that the population from the rural area could to self-insure the consumption of some foods, but considering the low level of other categories of expenses (the total expenditures in the countryside being of 332 dollars) the weight of the food becomes significant.

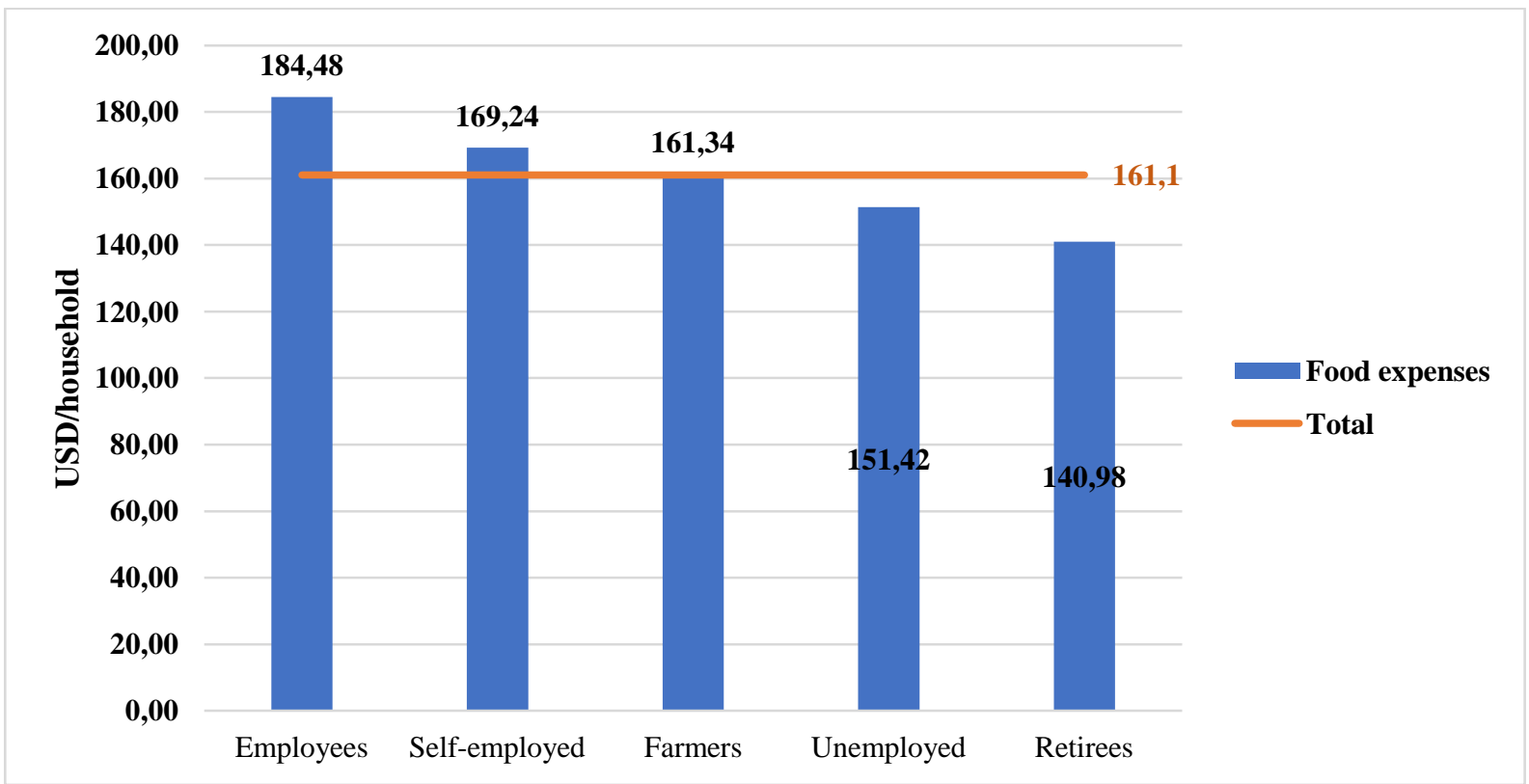

Figure 4. Average food consumption expenditures according to occupational status Source: own processing based on NIS data, http://statistici.insse.ro:8077/tempo-online/

Figure 4 shows the average value over the entire period taken into consideration of the food expenses according to the occupational status, thus, the group of employees assigns on average $\$$ 184.5 per household, being the highest value, above the national average with $14.5 \%$. The second place is the self-employed workers who spend about \$ 169 a month on food for the household, being above $5 \%$ on average, and very close to the average are the farmers whose food expenses are only $\$$ 161.34. $0.15 \%$ more than the national average. Below average are unemployed people who have a level of food expenses of $\$ 151$ (6\% below average) and pensioners with $\$ 141$, respectively $12.5 \%$ below average.

In order to be able to analyze the dynamics of consumer spending, it is further proposed to analyze the incomes obtained by a household. 


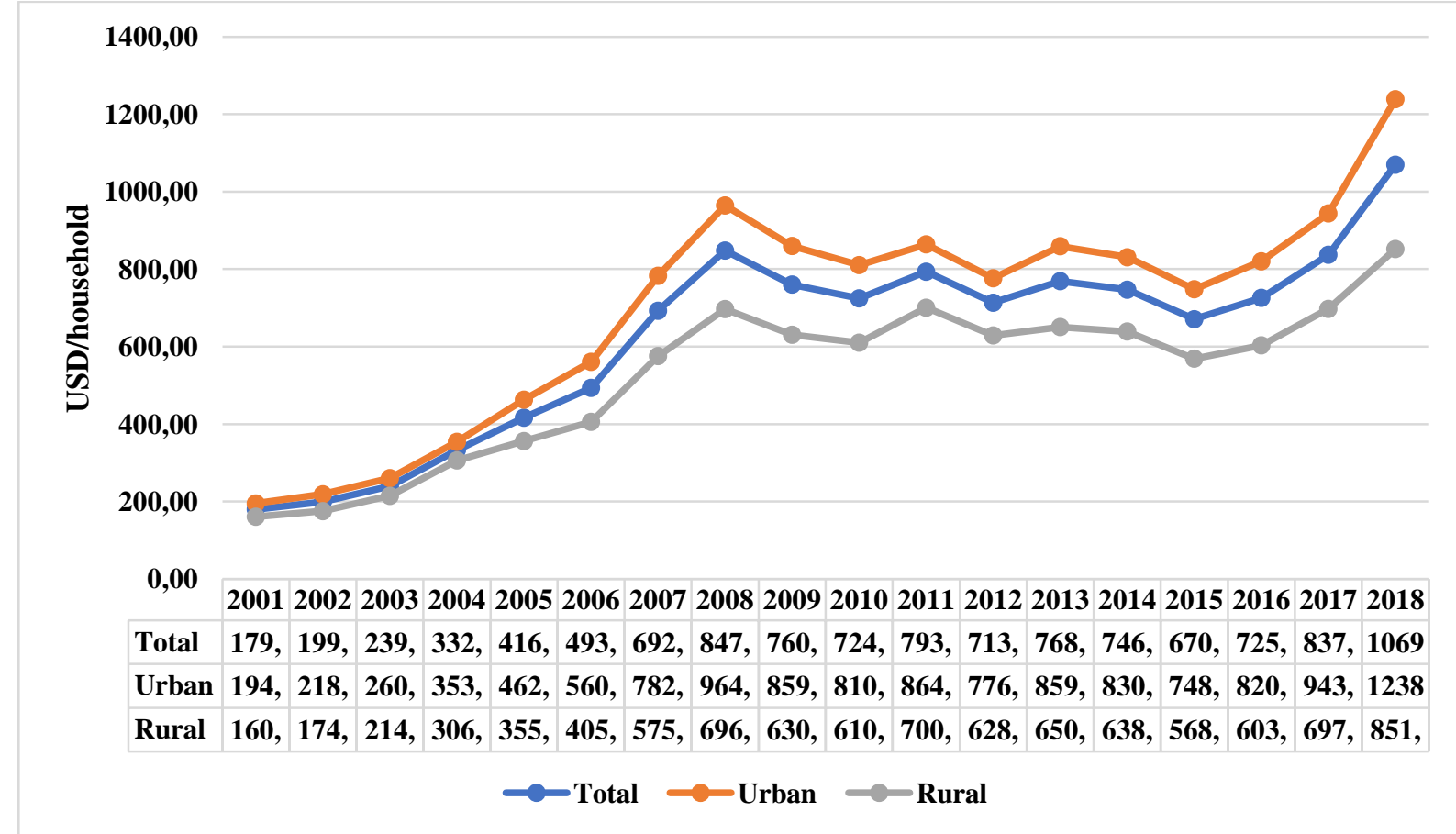

Figure 5. Evolution of total household income in Romania by residence area Source: own processing based on NIS data, http://statistici.insse.ro:8077/tempo-online/

In figure 5 it is proposed to analyze the evolution of the total income in a similar way to the one of the expenses, thus, we can observe a very similar trend, of growth, starting from a value of about $\$$ 180 per household, reaching 848 dollars in 2008 and to the maximum recorded in the last year, of 1070 dollars. On average there is an annual growth rate of $11 \%$ and an average value of income of $\$$ 622.8 per household, being higher than that of expenses (with about \$225). Similarly, the value of urban incomes is higher than the average, with $11.9 \%$, and the rural income is lower than the average, with $15.5 \%$.

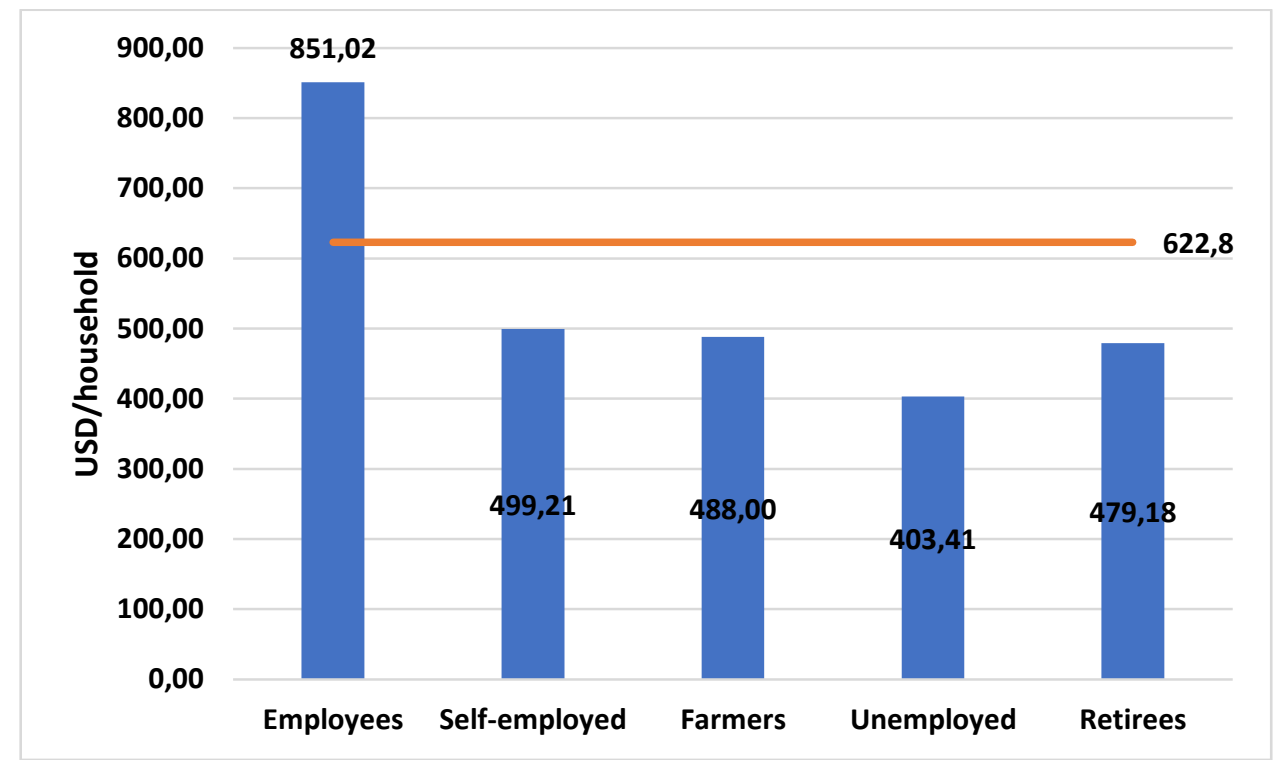

Figure 6. Total average income according to occupational status

Source: own processing based on NIS data, http://statistici.insse.ro:8077/tempo-online/ 
Analyzing according to the occupational status, only employees (as in the case of expenses) register a value higher than the national average, being 851 dollars, respectively $36.6 \%$ higher. Selfemployed workers have a total income of $\$ 500$, with an average of $19.85 \%$. Farmers earn $\$ 488$ (below average $21.65 \%$ ), unemployed people also average $\$ 403$ (below average 35.23\%), and retirees record income around 479 . dollars, being below the average by $23 \%$.

It is considered appropriate in this research and the analysis of the number of household members, thus proposing a similar analysis of this indicator.

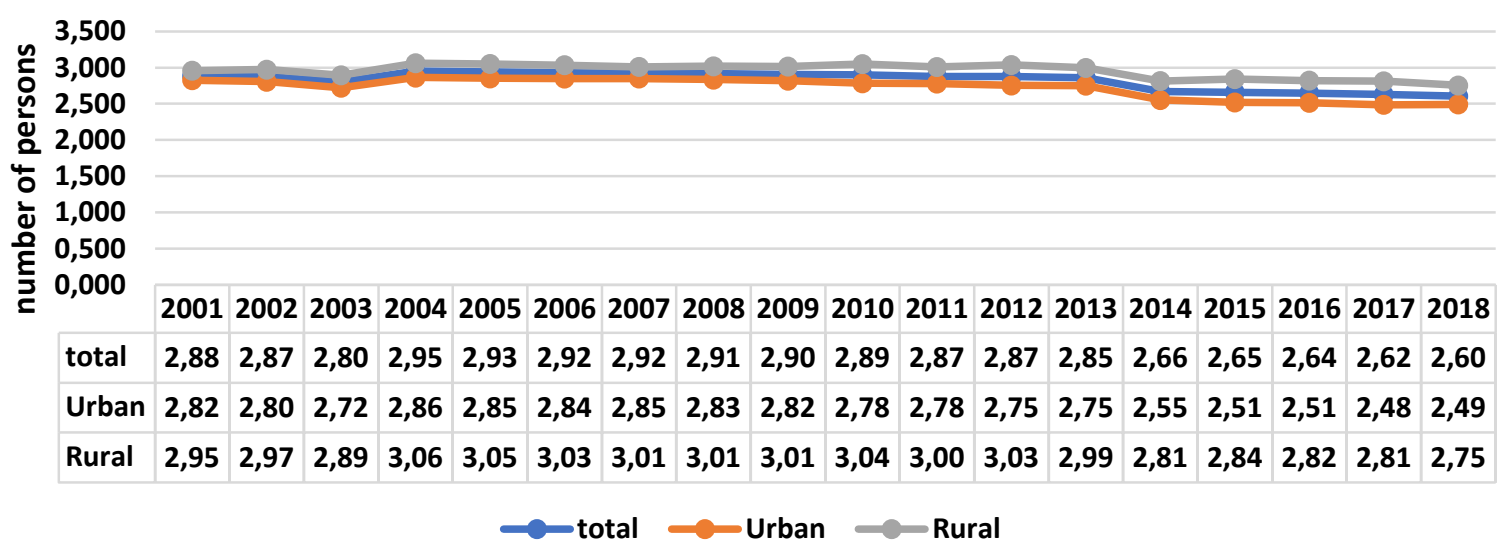

Figure 7. Evolution of the number of members of a household by residence area Source: own processing based on NIS data, http://statistici.insse.ro:8077/tempo-online/

From figure 7 it can be seen that the number of members, regardless of whether it is the national one or the members of the residence, registered a similar tendency, respectively slightly decreasing. Thus, if in 2001 a household comprised about 2.88 members, 18 years later, the average household comprised 2.6 members with a decrease of $9.7 \%$, with an average annual rate of $-0.59 \%$. Different from the situation presented so far is that, the largest number of members per household is in the rural area, on average 2.95 persons ( $4.5 \%$ more), and in the urban area a household has, on average, 2,725 members, $3.5 \%$ less than the national average (of 2.82 members per household).

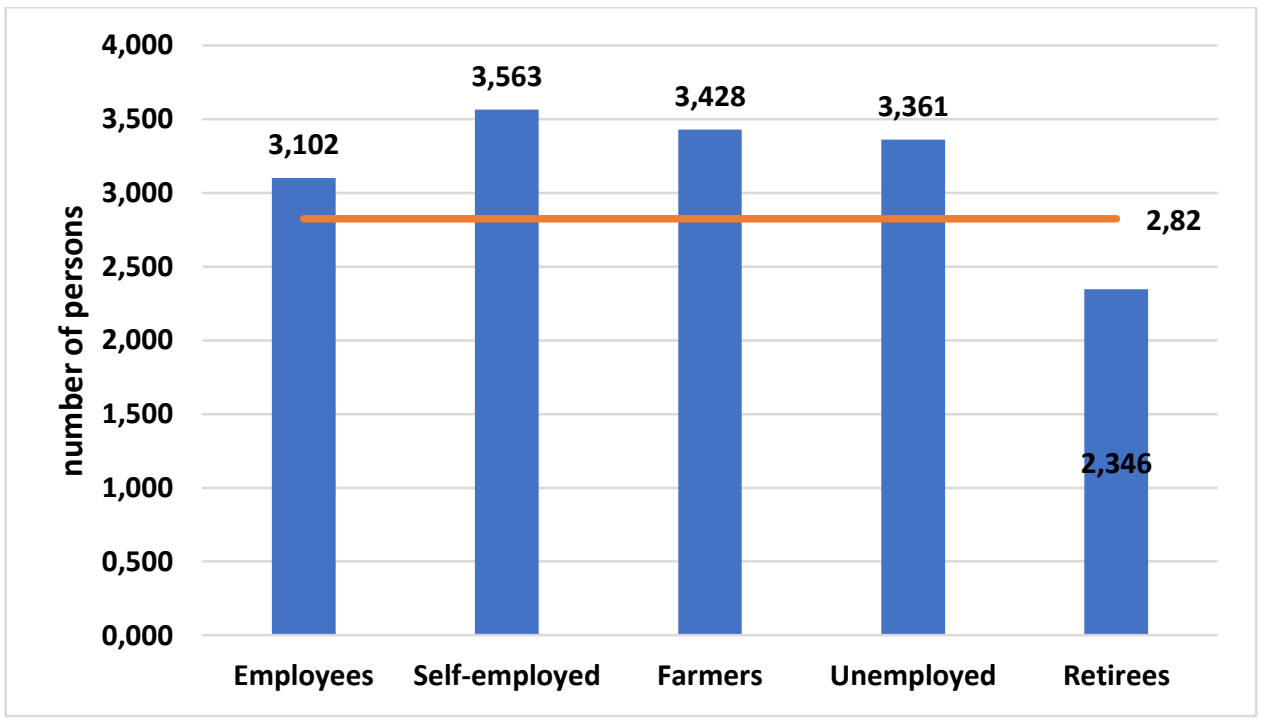

Figure 8. Average number of members according to occupational status Source: own processing based on NIS data, http://statistici.insse.ro:8077/tempo-online/ 
Regarding the number of members of the household according to the occupational status, as can be seen in figure 8 , most occupations have households with more members than the national average, apart from the category of pensioners who are on average about 2.35 per household. with about $17 \%$ below average.

In order to be able to determine the influences between these analyzed indicators, it is further proposed to determine the correlation coefficient (Pearson) in order to be able to determine the level of the links between these variables.

Tabelul 1. Determination of correlation coefficient between variables

\begin{tabular}{|c|c|c|c|c|c|}
\hline & & Total_expenses & $\begin{array}{c}\text { Total_Food_Ex } \\
\text { penses }\end{array}$ & $\begin{array}{c}\text { Total_incom } \\
\text { e }\end{array}$ & No.Members \\
\hline \multirow{4}{*}{ Total_expenses } & Pearson Correlation & 1 & $.968^{* * *}$ & $.986^{* *}$ & -.361 \\
\hline & Sig. (2-tailed) & & .000 & .000 & .141 \\
\hline & $\mathrm{N}$ & 18 & 18 & 18 & 18 \\
\hline & Pearson Correlation & $.968^{* *}$ & 1 & $.919^{* * *}$ & -.153 \\
\hline \multirow[t]{3}{*}{ Total_Food_Expenses } & Sig. (2-tailed) & .000 & & .000 & .543 \\
\hline & $\mathrm{N}$ & 18 & 18 & 18 & 18 \\
\hline & Pearson Correlation & $986^{* *}$ & $.919^{* * *}$ & 1 & -.451 \\
\hline \multirow[t]{3}{*}{ Total_income } & Sig. (2-tailed) & .000 & .000 & & .060 \\
\hline & $\mathrm{N}$ & 18 & 18 & 18 & 18 \\
\hline & Pearson Correlation & -.361 & -.153 & -.451 & 1 \\
\hline \multirow[t]{2}{*}{ No.Members } & Sig. (2-tailed) & .141 & .543 & .060 & \\
\hline & $\mathrm{N}$ & 18 & 18 & 18 & 18 \\
\hline
\end{tabular}

**. Correlation is significant at the 0.01 level (2-tailed).

Source: own calculations using SPSS

Analyzing the correlation coefficients it can be observed that between the total expenditures, the food and the income, there are very close relationships, with correlation coefficients being registered between 0.919 and 0.986 , thus it can be seen that these relations are strong.

On the other hand, it is surprising that the number of members of a household is not correlated with any of the indicators mentioned above, with very high values of the indicator Sig (signifiance), and negative correlation coefficients, so when the number of members decreases, income and / or expenses increase, which is very unlikely.

Thus, following the determination of the correlation coefficients, it is proposed to determine the equations by simple linear regression analysis for 2 models, respectively between total consumption expenditures and total incomes, and the second model between consumption food expenditures and total incomes.

Tabelul 2. The simple linear regression model between Total Expenses and Total Income

\begin{tabular}{|c|c|c|c|c|c|c|c|c|}
\hline Model & $\mathrm{R}$ & R Square & $\begin{array}{l}\text { Adjusted R } \\
\text { Square }\end{array}$ & $\begin{array}{l}\text { Std. Error of } \\
\text { the Estimate }\end{array}$ & & & & \\
\hline 1 & $.986^{\mathrm{a}}$ & .972 & .970 & 24.59353 & & & & \\
\hline \multicolumn{9}{|c|}{$\begin{array}{l}\text { a. Predictors: (Constant), Total_income } \\
\text { Coefficientsa }\end{array}$} \\
\hline \multirow[t]{2}{*}{ Model } & & \multicolumn{2}{|c|}{$\begin{array}{l}\text { Unstandardized } \\
\text { Coefficients }\end{array}$} & \multirow{2}{*}{$\begin{array}{c}\text { Standardized } \\
\text { Coefficients } \\
\text { Beta }\end{array}$} & \multirow[t]{2}{*}{$\mathrm{t}$} & \multirow[t]{2}{*}{ Sig. } & \multicolumn{2}{|c|}{$\begin{array}{l}95.0 \% \text { Confidence Interval } \\
\text { for B }\end{array}$} \\
\hline & & B & Std. Error & & & & $\begin{array}{l}\text { Lower } \\
\text { Bound }\end{array}$ & $\begin{array}{l}\text { Upper } \\
\text { Bound }\end{array}$ \\
\hline \multirow[t]{2}{*}{1} & stant) & 51.6 & 15.817 & & 3.268 & .005 & 18.155 & 85.218 \\
\hline & L_income & & .024 & .986 & 23.534 & .000 & .506 & .606 \\
\hline
\end{tabular}

a. Dependent Variable: Total_expenses

Source: own calculations using SPSS 
By developing the first statistical model in the SPSS program, one can observe a directly dependency relation between the total expenses and the total income, registering a correlation coefficient (R) of 0.986 and a coefficient of determination of 0.972 (thus the variables are explained in proportion of 97\%). Also the statistical model is valid, the Sig value being lower than the 0.05 threshold, and the confidence interval does not contain the null value.

By creating the model it was possible to determine the equation that explains the dependence between total consumption expenditures (dependent variable) and total income (independent variable)

$$
\text { Total_expenses }=0,556 * \text { Total_income }+51,687
$$

Thus, when the total household income increases by one unit $(\$ 1)$, the total consumption expenditure per household increases by 0.556 units $(\$ 0.556)$.

Tabelul 3. The simple linear regression model between Food expenditure and Total income

\begin{tabular}{|c|c|c|c|c|c|c|c|c|}
\hline Model & $\mathrm{R}$ & R Square & $\begin{array}{l}\text { Adjusted R } \\
\text { Square }\end{array}$ & $\begin{array}{l}\text { Std. Error of } \\
\text { the Estimate }\end{array}$ & & & & \\
\hline 1 & $.919^{\mathrm{a}}$ & .845 & .836 & 20.05585 & & & & \\
\hline \multicolumn{9}{|c|}{$\begin{array}{l}\text { a. Predictors: (Constant), Total_income } \\
\text { Coefficientsa }\end{array}$} \\
\hline \multirow[t]{2}{*}{ Model } & & \multicolumn{2}{|c|}{$\begin{array}{l}\text { Unstandardized } \\
\text { Coefficients }\end{array}$} & \multirow{2}{*}{$\begin{array}{c}\text { Standardized } \\
\text { Coefficients } \\
\text { Beta }\end{array}$} & \multirow[t]{2}{*}{$\mathrm{t}$} & \multirow[t]{2}{*}{ Sig. } & \multicolumn{2}{|c|}{$\begin{array}{l}95.0 \% \text { Confidence Interval for } \\
\text { B }\end{array}$} \\
\hline & & $\mathrm{B}$ & Std. Error & & & & Lower Bound & Upper Bound \\
\hline \multirow{2}{*}{1} & (Constant) & 48.9 & 12.899 & & 3.794 & .002 & 21.595 & 76.284 \\
\hline & Total_income & & .019 & .919 & 9.346 & .000 & .139 & .221 \\
\hline
\end{tabular}

a. Dependent Variable: Total_Food_Expenses

Source: own calculations using SPSS

Similarly, analyzing the linear regression between the dependent variable (consumption food expenditures) and the same independent variable (total income), we note a correlation coefficient of 0.919 which denotes a strong relationship between variables and a coefficient of determination of 0.845 which means that the variables dependents are explained in proportion of $84.5 \%$. The value of Sig being less than 0.05 , and the confidence interval not having reached the figure $0 \mathrm{can}$ be considered that this model is significant (valid).

Thus, it was possible to determine the equation of the right, respectively to determine the consumption food expenses according to the total income.

Total_Food_Expenses $=0,18 *$ Total_income $+48,939$

It can be appreciated that, when the income increases by one unit (1 dollar), the consumption expenses of a household increase by 0.18 units, respectively by $\$ 0.18$, in this case.

\section{Conclusions}

In this paper, we wanted to analyze the consumption expenses, both of the total ones, but especially of the food expenses in Romania. In the last 18 years, consumer spending has increased considerably, especially in the first part of the period, respectively until Romania's accession to the European Union, and in the last period, they have fluctuated, but also with an increasing tendency.

Analyzing the consumption food expenditures, they followed a similar trend with the total consumption expenditures, the first ones having a share of, on average, $40.5 \%$ of the total ones. Increasing expenditures, both total and food, can be attributed to the increase of the quantities purchased, the increase of prices (or inflation), the change of the way of life or the increase of the incomes.

Of these alleged reasons that could lead to the evolution of consumer spending, considering that the demographic development could not be a reason, simply because the population of Romania is declining, but also by the present analysis which shows that the average number of households is decreasing, it was considered appropriate to analyze the evolution of average incomes per household. 
This indicator has registered trends similar to those of consumer spending, but with a faster average annual rate, thus the level of incomes being higher than that of expenses.

Both the level of expenditures (either total or food), as well as the level of incomes were higher in the urban area (by 3-12\%) than the national average, and in the rural area they were lower by $4-16 \%$ than the average per the country.

By analyzing the correlation coefficients, it was possible to determine 2 statistically viable models, linear regression models, which could analyze the total consumption and food expenses according to the total income. Thus, when the total average income per household increases by one-unit, total expenditures increased by 0.556 units, and food expenses increased by 0.18 units.

Both from this analysis and from the table of correlation coefficients it can be observed that the influence of external factors on food expenditure is small, considering that from the budget allocated to expenditure, per household, the category of food is the most constant, according to the theory of the agri-food economy. .

\section{References}

[1] Khanal B, Banskota K and Giri D 2017 Comparative Analysis of Food Expenditure Pattern

[2] Alexandri C and Păuna B 2015 Assessment of Food Consumption Diversity for Romanian Facultatea de Management Agricol XVII (1) pp. 282-289

[3] Petrovici, D and Ritson, C 2000 Food consumption patterns in Romania British Food Journal 102 pp.290-308. 10.1108/00070700010327724.

[4] Kingdom of Netherlands 2016 Food Market in Romania Embassy of the Kingdom of the Netherlands in Romania p.8 https://www.dutchromaniannetwork.nl/wpcontent/uploads/2017/01/Food-Report-Romania-2016.pdf

of Nepalese Households Using Engel Curves Journal of Business and Social Sciences Research 2 pp. 27-46

[5] National Institute of Statistics (NIS) www.insse.ro 